\section{BA Institute of \\ YK Business Administration \\ 页下 \\ Karachi \\ Leadership and Ideas for Tomorrow}

\section{Business Review}

\section{Volume 10 Issue 2} July-December 2015

7-1-2015

\title{
US Policy of technology transfer to China
}

Amna Mehmood

International Islamic University, Islamabad

Sadaf Farooq

International Islamic University, Islamabad

Follow this and additional works at: https://ir.iba.edu.pk/businessreview

Part of the International Business Commons, Political Economy Commons, and the Technology and Innovation Commons

\section{(c) (1)}

This work is licensed under a Creative Commons Attribution 4.0 International License.

\section{Recommended Citation}

Mehmood, A., \& Farooq, S. (2015). US Policy of technology transfer to China. Business Review, 10(2), 66-82. Retrieved from https://doi.org/10.54784/1990-6587.1354 


\title{
ARTICLE
}

\section{US POLICY OF TECHNOLOGY TRANSFER TO CHINA}

\author{
Amna Mahmood \\ International Islamic University, Islamabad \\ Sadaf Farooq \\ International Islamic University, Islamabad
}

\begin{abstract}
Hans Morgenthau defined international politics as the struggle for power among nations. Initially power was understood in terms of security and military supremacy only. But time has proved that military power is only effective when it is supported by a strong economy. Especially in post-Cold War era when the world is transforming from uni-polar to multi-polar world on the basis of competing economic centres, political economy has attained equal importance at par with the international security studies, if not more. One of the most important and sensitive area of international political economy is technology transfer, a life blood for modernization of a developing economy. No doubt the US started relations with China due to the strategic considerations against the USSR, but it could not ignore the temptation to capture a market of more than one billion people. For People's Republic of China (PRC) one of the major objectives for the opening towards the West was thrust for modern technology for its four modernisations. In the post-Cold War era, with the demise of the Soviet Union (USSR), strategic relations lost its relevance and commercial relations became at the core. Trade, which started from virtually nil, became multi-fold in 1990s, still was troubled because the United States (US) was not ready to sale what China wanted for its technological advancement. The reason was that in the US, technology transfer is carried out by private actors. But framework, which regulates the technology transfers, is controlled by the policy makers who could not get rid of the Cold War mindset that PRC was a communist state, a threat to the 'free world.' This paper covers the US policy of technology transfer in the domain of military, nuclear and satellite technology, level of cooperation, legislations and issues in technology transfers and finally its impact on bilateral relations. It concludes that the US used technology transfers as a contrivance to advance its policy goals in China but technology denial led China to the alternative sources and the US lost its leverage to bargain on policy options. The US entrepreneurs also had to bear the cost in terms of lost business.
\end{abstract}

Key words: technology transfers, military, nuclear, satellite, alternative sources.

\section{Introduction}

The policy of technology transfers is used as a mean to promote the national security and foreign policy objectives of the US. The incentive to transfer or the threat to withhold or complete refusal of technology transfer is a major tool to influence the policies of target state. It is also an instrument to punish certain undesired actions of friends or foes or to register 
https://ir.iba.edu.pk/businessreview/vol10/iss2/5

DOI: https://doi.org/10.54784/1990-6587.1354

Business Review - Volume 10 Number 2

July - December 2015

protest against their policies. The potential of success for this 'economic state craft' depends on many factors including domestic consensus, the degree of international co-operation and the vulnerability of the target state. Nonetheless using the technology transfer as an instrument, policy makers need a careful balancing of competing policy goals, otherwise it may be counterproductive. Moreover it is also a difficult task to achieve domestic and international support simultaneously. A possibility remains always there that the target country can move to the alternative sources or depends on its own. In that case, sanctions on technology transfer may lose their effectiveness (Yuan, 1995).

The US policy of technology transfer was no exception. It was designed to balance two contradictory goals. The first was to protect the national security through restricting the export of dual use technology that could upgrade the military capabilities of China. The other was ensuring the promotion of bilateral trade between the two countries. Section I of this paper gives a brief literature review on the topic. Section II of this article deals with the normalization of relation and hurdles due to Tiananmen incidence. Section III deals with the technology transfers in the field of satellite, military and nuclear technologies to PRC, while section IV discusses the US sanctions on technology transfers to China and China's turn to alternative sources. The final section concludes the study.

\section{Review of Literature}

Tan Qingshan, in his book Making of US-China Policy: From Normalization to the post-Cold-War Era has evaluated US policy toward China since normalization, exploring the importance of government institutions, the interactions among those institutions, and the roles that specific individuals have played in policymaking. According to him, U.S. policy toward China is not always guided by strategic considerations and that Congress and the bureaucracy have a critical impact on policy outcomes. He examines the U.S. political process and its impact on policymaking toward China. He has focused on four case studies: the Taiwan Relations Act, U.S. arms sales to Taiwan, the U.S.-China trade agreement and U.S. technology transfers to China (Qingshan, 1992).

Henry R.Nau,Jack H. Behrman and Harvey W. Wallender in Technology transfer and U.S. foreign policyhas examined historical practices associated with the use of U.S. technology in foreign affairs, whether this use involved strategic, diplomatic, commercial, or other aims and whether the technology was destined for advanced, socialist, resource-rich, or resource-poor developing countries. Along with that, it has also examined several specific case studies of recent technology outflows to various groups of countries. These inquiries reveal the increasing economic as well as strategic and diplomatic significance of USA technology in foreign affairs. A framework of policy motives and mechanisms and different types of technological exports, plus four interesting case studies have been given to describe in detail how affiliates of large enterprises get technological help not easily obtainable by others (Nau,Behrman \& Wallender, 1976).

Wang Jisi, in China at the CrossroadsSustainability, Economy, Security and Critical Issues for the 21st Centuryreflects on Chinese political reform and asks whether or not its leaders are actively laying the path towards democracy. According to the author, after three decades of rapid growth, the country now finds itself at an economic, political and foreign policy crossroads. The fourteen contributors address some of the economic, environmental and social fragilities that this prosperity and opening up has created (i.e. income inequality, environmental degradation, excessive trade surpluses), but they maintain their praise for Deng Xiaoping's economic opening which they credit for making China more prosperous as it become more politically stable. The writers have addressed the progress made over the past three decades from revamped tax, banking, pension, legal and regulatory systems, new 
infrastructure such as high-speed railways systems, jobs, and assisting the world through investment and trade. However, the economic growth and openness has created a far more complex, demanding and complicated society, as well as created complications with its neighbours and the west. Some fragility has been created by rapid progress such as lack of access to health and education, environmental degradation, corruption and income inequality. But at the end they have maintained their praise for Deng Xiaoping's economic opening which they credit for making China more prosperous as it become more politically stable. While the examples and means by which China has developed and prospered are well made, the future progress is blocked by United States led discrimination and political interference, and an inequitable international order which frames China as a threat (Jisi, 2012).

Rosemary Foot in The Practice of Power: US Relations with ChinaSince 1949has put together a richly detailed analysis of the change in American relations with China after 1949 from hostility to rapprochement, and to full normalization of the ties in 1979. She has focused on the relationship after normalization, a period when the United States has come to view China as less of a challenge but still resistant to certain of the norms of the current international order. The book begins by examining US efforts to build, and then maintain an international and domestic consensus behind its China policy. It then looks at changing US perceptions of the capabilities of the Chinese state. It shows how American positions on Chinese representation at the UN and on the trade embargo were subtly eroded, not least by changes in US domestic public opinion. The author argues that previous explanations of American relations with China have narrowly focused on ideas associated with the strategic triangle and that instead we need to embed our understanding of the evolution of American relations with China within a wider structure of relationships at the global and domestic level (Foot, 1995).

Otto Schnepp in the paper U. S. -China Technology Transfer: Problems and Solutions presents a descriptive portrait of the U.S-China technology transfer process. China projects of Foxboro (industrial controllers -- a joint venture), Cummins (diesel engines -licensing), and Westinghouse and Combustion Engineering (electric power generation equipment -- licensing) and promotional policies supporting expanded trade and technology transfer through financing and other means have also been addressed. Apart from that, the writer has also discussed that Congress reviews overall U.S. foreign policy toward China to assess the success of past policies and to anticipate future problems and policies toward China reflect perceptions of the global role of the US (Schnepp, 2008).

Theodor Leuenberger in From Technology Transfer to Technology Management in China has explained why China has failed to implement a strategy of expanding its economic policy. The actual cause behind this failure is not the technologicalproblems but the methods, organizational questions, reflexes and attitudes that prevent the use of modern technologiesin an efficient and profitable manner. Whenever the Chinese talk about foreignmade tools or foreign-designed systems which they are using or have borrowed, they are always careful of emphasizing Chinese Character. There is a dire need to take an integrated approach to manage technological development, adopt a coordinated strategy, and continue and deepen economic and structural reforms (Leuenberger, 2012).

Allan C. Reddy in A Macro Perspective on Technology Transfer has introduced the concepts related to technology transfer, discussed the major participants in the worldwide transfer enterprise and presented ways to overcome the barriers in technology transfer. He has emphasized on the need for, and methods to, transfer technology to LDCs, provided ways to analyze the costs, and presented a model of reciprocal distribution that may benefit both the donor and the recipient country in the transfer process. According to him, the key to 
economic success, particularly for the less developed countries of the world, is technology-but only when properly applied. Despite years of help through technology transfer, however, many LDCs are still impoverished because either the wrong technologies were transferred or the right ones were not transferred. The countries can improve their economic growth through technology transfer, by assimilating technology into their socioeconomic and cultural structures that is critical to their economic development, not the indiscriminate borrowing from advanced nations (Reddy, 1996).

From the normalisation, in 1979, the US technology transfer policies reflected that the benefits of increased technology sales to China had overcome the risks. The restrictions on high technology exports to China had gradually been eased through the Export Administration Act amendments of 1977. This act in its amended form relaxed 'the equally restrictive trade policy' towards all socialist countries. It also empowered the US President to regulate trade with different communist countries. President Carter used the provision to shift China from the more restrictive trade classification of country group $Y$, to a new classification, country group P. This classification was created especially for China while the previous classification was reserved for Soviet bloc. This new classification enabled the Department of Commerce to facilitate the sale of high-technology civilian goods with possible military applications to PRC (Qingshan, 1992, p 116-17).

President Reagan, in continuation of the policies initiated by his predecessor, further liberalised technology transfer to China. The administration issued a directive allowing the sale of high technology and equipment to China at technology levels, twice to those approved for the USSR. The administration further reformed the policy of technology transfer to China, moving it from country group $\mathrm{P}$ to country group V. It was the same trade classification, given to Japan and Western Europe. But to block free flow of technology at par with above mentioned countries a new 'zone system' was established. The goal was to restrict certain kind of exports to China, in the national security interest and to speed up the review of applications for non-sensitive exports by providing clear guideline to licensing review officers. Interagency steering group on technology transfer to China established the three guidelines. Those guidelines included the green zone-routine licensing approval, the intermediate or yellow zone case-by-case license review; and the red zone-most advanced technologies sensitive to national security. The US Commerce Department reviewed the cases falling in the first category, the green zone. Those falling in the yellow zone were reviewed by both Department of Defence and the Department of Commerce on case-by-case basis. Those enlisted in the red zone were considered by the Department of Defence and the Department of State both, deemed as a substantial threat to the US national security (Hanshan \& Morrison, 2000).

The commerce Department highlighted seven commodity areas for special attention in license reviews. These seven areas consisted of three-quarters of US export license applications for China. They were computers, computerised instruments, recording equipment, semiconductor production equipment, microcircuits, electronic instruments, and oscilloscopes. For the red zone items, no list had been published. According to the State Department, red zone included nuclear weapons and delivery systems. It also included technologies and equipment used for intelligence activities, electronic warfare, antisubmarine warfare, power projection and avionics (Hanshan \& Morrison, 2000).

The new policy ended the confusion of the double standards and accelerated the process of bureaucratic reviews for licenses. Consequently the administration approved about 2,000 cases worth about $\$ 500$ million for exports to China in 1982. While in 1983, it approved over 3,000 cases worth over $\$ 1$ billion. Next year in 1984, the administration 
approved 5,000 cases with the total value of about $\$ 2$ billion. Despite these approvals, double-standard treatment with regard to technology transfer to China continued. Although China was kept under category V, albeit most of the dual use technology transfer cases continued to be reviewed on a case-by-case basis (Hanshan \& Morrison, 2000). This policy continued till 1989 when the Tiananmen incidence hampered the process.

\section{Post-Tiananmen Sanctions and their Implications}

The Tiananmen incidence (BBC News, 1989) ${ }^{1}$ ended the domestic support in the US for pro-China policy. Bush (Sr.) administration responded the Tiananmen incident by introducing a series of sanctions against China. First, the administration suspended all the high level exchanges. They announced a complete ban on military sales to China with immediate effect (Yuan, 2003) ${ }^{2}$. These sanctions also affected commercial exports of dual use technology items to China which were on the US Munitions Control List (MCL).

Bush (Sr.) administration further controlled the processing of green zone cases. It also proposed such control by the Coordinating Committee for Multilateral Export Controls (COCOM) members. The suspension of all high-level government exchanges was accompanied by prohibitions on loans to China from Export Import Bank programme; Overseas Private Investment Corporation; withholding International Development Association loans; and opposition to loans from multilateral development banks including the World Bank and the Asian Development Bank (Yuan, 1996, p 317-18).

The suspension of advanced technology transfer had a serious consequence on China's struggle to modernise its high technology industries. The civilian industries particularly the aerospace, computer, electronics, nuclear energy and telecommunications sector fell in trouble. However these sanctions were tough in outlook but swift in nature. They did not lead to the complete reversal of United States' technology policy. One reason was that the Bush administration was convinced that the demise of Soviet threat did not end the significance of China in the post-Cold War security environment. China's active participation and co-operation in handling and resolving a number of issues having security concerns to the US were appreciated by the US administration. China's stand on Gulf-War, peace on Korean peninsula and political settlement in Cambodia were appreciated as supportive for the US foreign policy. President Bush sent Brent Scowcroft, his National Security Advisor, and Lawrence Eagleburger, his Deputy Secretary of State (Bush, 2011)immediately after Tiananmen, to China though the official exchanges remained suspended. It was the evidence of engagement policy and continuity of constructive dialogue (Washington Post, 1989).

The other reason was the economic costs of the sanctions. The COCOM allies agreed that the military sales to China should be banned adopting strict policy in future. At the same time, the US was aware of the strong reaction from the members if the past agreements were rolled back. Without allies' co-operation, unilateral action by United States

\footnotetext{
${ }^{1}$ Demonstrators, mostly students, were demanding for democratic reform occupied the Tiananmen Square for seven weeks. They refused to move until their demands were met. PLA moved into the square from several directions, late on 3 June 1989, randomly firing on unarmed protesters, killing hundreds of civilians.

${ }^{2}$ Those included four major government to government projects: the $\$ 62.5$ million An/TPQ37 artillery locating radar packages; Mark-46 Mod-2 anti-submarine torpedoes worth $\$ 8.5$ million; \$28.5 million program to upgrade two $155 \mathrm{~mm}$ ammunition production facilities and the $\$ 550$ million Project Peace Pearl to upgrade the avionics for China's F-8 fighter interceptor.
} 
proved to be ineffective. Specially restrictions on exports of certain items based on their endusers or expected end-user, for example crime control and detection equipment for which the Chinese military and police force may be the end users, could not be effective without securing similar allied action. It would be both ineffective and costly. It was estimated that technology denial would result in a loss of $\$ 5$ billion annually to the US business, since China was expected to switch over to the alternative sources (Yuan, 1996. pp. 320-21).

Therefore both the US and COCOM either modified or liberalised the technology transfer sanctions, keeping the strategic and economic consideration of the US-China relations but the policy of preferential treatment was changed after the Tiananmen incidence. For example, when the Commerce Department lifted restrictions on computer sales to outlawed destination, China was also the beneficiary. Similarly when COCOM, in 1991, further liberalised control on a majority of the East European countries, the China preferential continued to exist, though on papers only. In fact except for 1989, technology transfer to China continued to ease slowly and steadily between 1990-93.

Bush administration allowed the delivery of four Boeings 757 commercial jetliner to China, worth \$200 million in July 1989. After three months, the administration allowed the Chinese military officers and technicians to return to their assignment at the US facilities to restore upgrading programme of F-8. The US President used his presidential waiver authority on at least seven occasions to allow the sale of US built satellite to China. The FMS equipment placed in storage for more than three years, due to ban on military sales was released for shipment in the last days of Bush administration (Yuhan, 1996).

\section{US SATELLITE EXPORT TO CHINA (1988-98)}

Under the sanctions imposed after the Tiananmen Square incidence in 1989, satellite export to China either for launch or for sale was subjected to presidential waivers. Since 1991, Presidents George Bush and Bill Clinton issued eleven waivers allowing the export of satellites to China for launches, including three from the former and eight from the later. China had launched twenty US-made satellites for the US, itself, and others. The presidential waivers enabled the US satellite manufacturer companies to take advantage of China's cheaper space launch prices. ${ }^{3}$

Although the US president was considerate towards China but the Congress responded aggressively on Tiananmen Square incidence. It passed Foreign Relations Authorisation Act (P.L. 101-246, Section-902), under the FY 1990 (P.L. 101-162) and the 1990-91 imposing strict sanctions on the export of US built satellites to China. Since the communication satellites were also enlisted in the military item list therefore they were also kept under the US State Department's Munitions List (MCL). The President could waive the sanctions on the certification that it was in the US national interest or he might grant a waiver by reporting the US Congress 'that China had achieved certain political and human right reforms.' This wavier was granted three times by the US president 1989-1992 in the name of national interests to allow many satellite project with China. However political analysts took it as a conciliatory move, to compensate China for the sale of F-16s to Taiwan.

${ }^{3}$ The Chinese prices were much lower ranging from $\$ 12$ million to $\$ 70$ million per launch, than those charged by the US companies, ranging from $\$ 50$ million to over $\$ 100$ million per launch. 
The US government again revived sanctions on August 25, 1993, due to China's ballistic missile proliferation activities. During this period acute tension was observed between the US business and policy makers. Businessmen' had viewpoint that the sanctions would destroy the US business interests while the policy makers believed that the sensitive technology should not be exported to China. The centre of debate was the control of the satellite export. The first category included the satellite manufacturers and those in favour of American business like Hughes and Lockheed Martin wanted its regulation by the Commerce Department's Control List. The second included the Congressmen, foreign office bureaucrats, old cold warrior and some in media wanted that it should be administer through the State Department's Munitions List. The issue was settled in favour of first group when in October 1996, primary responsibilities were transferred to the Commerce Department (Miller, 1998).

President Clinton allowed the export of China Sat 8 on the pretext of national interest in 1998 (Jr Fisher, 1998). Therefore Sino-US commercial space cooperation remained active and CGWIC successfully launched 26 US satellites into space. However, this cooperation ceased after June 1999when the US tightened its export controls following the Cox Report, which accused China of "illegally obtaining" US space technology (Report of the selected committee of the House of Representatives). ${ }^{4}$

Under the new policy, the US Congress passed a law "US International Traffic in Arms Regulations" in 1999 that placed all space-related hardware and services, regardless of sophistication or availability, on the U.S. Munitions List. ${ }^{5}$ This law adversely affected US satellite sales in the global market. Before the ban, some countries in Africa, Asia and Latin America preferred using China's satellite launch service for its relatively low costs and high success rate. But after the ban, as China could no longer launch satellites that use US satellite technologies therefore, some of those countries opted to buy satellites that were manufactured in Europe or China without ITAR-controlled components. Since 2005, China has made and launched communications satellites for Nigeria, Pakistan and Venezuela, and launched a number of satellites made by European companies for international clients. This law could not stop China's space advancement, rather helped to increase sales of Chinese made satellites. Realizing the recurring loss to the US business, Congress finally abolished it in 2013.

In order to stimulate commercial space sector, US export control rules were further revised in 2013 and a new law "National Defense Authorization Act" was passed that removed satellites and related items from the US Munitions List (Borst, Sarkani \& Mazzuchi, 2012). But still the US satellite hardware cannot be transferred to China, North Korea or to any countries that are considered state sponsors of terrorism. Chinese government and aerospace industry were disappointed on this law. They urged the US administration and Congress to review its Cold War mindset and separate an entirely commercial activity from politics. Shen Danyang, official spokesman of Chinese government, lamented that "The US has not fulfilled its promise to benefit China in its reform of the export control system and boost exports of high-tech equipment to China, the US rolled out measures to hinder satellite cooperation for civil purposes between the two countries." ProfessorZhou Shijian, ${ }^{6}$ analyzing US foreign policy also said that this law is not in conformity with US's stated policy of

\footnotetext{
4 This committee was established to investigate charges of theft and illegal satellite technology transfer by the US companies to China.

${ }^{5}$ This list is a registry of sensitive technologies whose exports are tightly controlled by the US Department of State.

${ }^{6}$ Professor Zhou Shijian, a senior trade expert and professor at Tsinghua University, China.
} 
cooperation with China. He further stated that China is not an enemy to the US and putting restrictions on China is not in mutual interests of both nations (Dingding, 2013).

\section{Military and Nuclear Technology Transfer}

After the diplomatic recognition in 1979, China was expecting that the US would help its military modernisation by providing sophisticated arms and advanced technology. But the US Congress and administration were not accepting the idea to fulfil the demand of arms supplies to a communist regime. However, the US did not hinder the Chinese defence purchases from its allied countries but avoided direct military exports (Nolt, 2001). Nonetheless China was also not prepared to join any formal defence pact with the US, but at least they were anticipating that under the strategic partnership, the US should help in replacing their obsolete arsenal by western modern weapons to attain military balance with the Soviet Union.

The US position was clear. It was willing to export technology but for civilian use only. Many policy makers had deep concerns that the transfer of dual-use technology to China would facilitate its military modernisation (Holtand Nikitin, 2015). Some policy makers and Congressmen also had strong apprehensions about the military capabilities of China and considered any effort to modernise Peoples' Liberation Army (PLA) of China as a threat to the US interests in Asia. Therefore, it opposed transfer of any type of military technology to China (Report of The Commission To Assess The Ballistic Missile Threat To The United States, 1998).

On the other hand China, keeping Taiwan Strait crisis in 1996 and US unilateralism in Iraq, expedited its already continued military modernisation from an army for 'protracted wars of attrition on its territory to one capable of fighting and winning short-duration, "highintensity conflicts against high-tech adversaries" based on information warfare (Stumbaum, 2009) In order to modernize its military, China decided to achieve two objectives. First, was to invest in tactical aviation and naval assets especially in carrier fleet to advance military capabilities of PLA Navy. China's anti-access denial (A2/AD) strategy prioritized investments in a number of areas including the development of advanced missile technologies, launching a robust network of intelligence and developing counter-space capabilities. Second, was to develop the defence industry not only to expand Chinese influence through defence exports but also to acquire self-sufficiency (Nurkin, at.el. 2014).

China's steady and significant modernisation was supported by increased investment. The official defence budget grew from \$20 billion in 2000 to $\$ 148$ billion in 2014 and is estimated to reach $\$ 189$ billion by 2018 . Currently, China's growing indigenous capability is increasing in the field of military aviation, shipbuilding, missile development, and space and its reliance on foreign technology has been considerably reduced. Now, China needs limited foreign technology to fill capability gaps, particularly around engines, advanced radars, and guidance systems (Nurkin, at.el. 2014).

Although the US, constrained by the threat of terrorism, wanted China to cooperate in war against terrorism, however, it also felt threatened by Chinese efforts to procure high technology considering it a potential challenge to its interests in Asia; therefore it refused to cooperate in this regard. It was also apprehensive about the security of Taiwan as China could militarily take over the Iceland with a strong PLA.

\section{Prospects for the US Nuclear Industries}

China's ambitious plans for its nuclear modernisation in 1980 s created new prospects for foreign nuclear industry to export nuclear technology to China. The nuclear 
technology development for peaceful had been given top priority in China's sixth and seventh five-year plans for the years 1981-85 and 1986-90. They were interested in purchasing foreign nuclear technology, equipment and engineering services for most of their projects. China declared the plan to generate $10,000 \mathrm{MW}$ through ten nuclear power plants, by the end of the century, to meet the increasing energy demands (Qingshan, 1992, p, 324).These nuclear projects presented attractive prospects for the US companies. Chinese wanted to deal with the US companies directly because the US was virtually the first to transfer the nuclear technology through the sale of complete nuclear plant. Although the French, German, and Japanese designs were based on the US nuclear reactors models but the latter had certain advantage being the original one. But in the absence of an agreement for nuclear cooperation with China, the US companies were not able to participate in the Chinese nuclear project bids. Despite their deep interest, they lost the opportunities to their competitors. The US companies did their best to persuade the Chinese authorities to defer their decisions about giving contracts, for two 900MW units, to French and British companies until they would be in a position to participate in the bid. Chinese authorities could not help, since there were no prospects of a US-China nuclear agreement in early 1985 (Ibid.).

Even after signing of the US-China nuclear deal in later half of 1985 it could not be implemented till 1997. The primary cause for non-implementation of the nuclear agreement had been the controversial issues of China's 'arms sales and technology transfer in the late 1980s.' The American Secretary of State, George Shultz and the Secretary of Defence, Frank Carlucce, visited China in July, and September 1988 respectively. The prime motive was to convey the United State's serious concern over arms sales to Iran and Saudi Arabia, and planned sales to Syria. The sanctions were lifted on the assurance from Beijing that China would make no future military technology exports (Yuan, 1996, p 324).

The US policy makers remained suspicious about China's involvement in proliferation activities in the regions, which the US considered volatile for the world's balance of power (CNN News, 1998). They used technology transfers as a policy instrument to check China's proliferation activities. Under the engagement policy both governments continued dialogue. As a result China agreed to sign international covenant on nonproliferation of nuclear and missile technology but the US Congress remained dubious about nuclear technology transfer to China therefore, no US President could issue the necessary certification required under P.L. 99-183. In 1997, Clinton became the first who issued the required certification enabling the implementation of that agreement with China (Dumbaugh,2007). It showed the sign of improvement in bilateral security-relations.

No significant progress in bilateral nuclear relations was seen under Bush (Jr.) administration. His successor President Obama announced, in 2009, that a US-China nuclear partnership is essential to "seek the peace and security of a world without nuclear weapons." But the tension could not be eased and there was no practicality at official level. The Belfer Center's Managing the Atom (MTA) Project, in 2010, took the initiative to find out the solution to the problem and start "US-China cooperation across a broad agenda of issues."7 These negotiations included both "the US and Chinese approaches to prevent nuclear terrorism; Chinese nuclear weapons policies and perspectives on the US nuclear posture; reactions to the Prague arms control agenda; opportunities for strengthening cooperation on non-proliferation; and China's nuclear energy and commercial reprocessing plans." At a point

\footnotetext{
${ }^{7}$ These "discussions were part of an ongoing MTA research initiative on China's nuclear policies, led by Zhang, and made possible by generous support from the Carnegie Corporation of New York and the John D. and Catherine T. MacArthur Foundation."
} 
when the US needed China's support to extend the UN sanctions on Iraq and wanted its participation in the Nuclear Security Summit such dialogues were considered, a move to address the trust deficit of both sides on each other and to suggest good policy options to the policy makers of both nations (Malin, 2010).

The move proved successful and in January 2011 both the countries decided to construct the Centre of Excellence on Nuclear Security in Beijing. Work on the project started in October 2013 and is expected to be completed in 2015. This project would help China to increase its domestic nuclear-security capability It will house environmental laboratory space, test sites and areas where atomic- security professionals can drill in their crisis-responses techniques. The centre also will include a focus on combating the illegal sale of atomic technologies (Working Began on Nuclear Security Centre in China, 2013).

Nuclear cooperation between the two countries is strengthening under Obama administration. Current areas of the cooperation include fostering common interests in nuclear energy collaboration among the US and Chinese scientists, laboratories, research institutes, and universities, extraction of uranium from seawater, and nuclear hybrid energy systems. Besides, both the countries are also cooperating in nuclear safety field including exchange of technical information, research results and experience exchange of personnel for visits and assignments; exchange of equipment, materials and instrumentation; and joint training, seminars, conferences, and workshops (Steering Committee Meeting of US-China Bilateral Action Plan, 2014).

\section{NON-PROLIFERATION AND US SANCTIONS}

From 1989 to 1993, the United States imposed a number of highly publicised sanctions as a reaction to China's proliferation activities to the Third World including sales of M-9 and M-11 missiles to Pakistan. The US administration denied export licenses for highspeed computers to China because of violation of the Missile Control Regime (MTCR) guideline. The White House also announced more restricted approval of export licenses for the computers exceeding a certain level (New York Times, 1991).

In 1992, China signed an agreement to build two 300-megawatt nuclear reactors in Iran. Western media was suspecting a civilian cover for weapons programme (Gill, 1993). Sanctions on the export of high technology against China were lifted when it agreed to sign NPT, in 1992, providing written assurances to the US that it 'would adhere to the guidelines of MTCR.' Therefore the US government lifted. But the tension revived when in response to the reports of alleged technology transfer of M-11 missiles, Bush administration reconsidered the transfer of Cray supercomputer to China (Rennack,2006). In 1993, the Director of Central Intelligence Agency (CIA), James Woolsey, testified that "it is not clear whether Beijing has broken off contacts with elements associated with Pakistan's weapons program" (Reiss \& Litwak, 1994: pp, 148-49).

Despite frictions in relationship the overall policies of US administration continued the patterns of engagement. It also allowed the sale of 'computers with data processing speed up to 67 million theoretical operations per second (MTOPS).'The US Commerce Department approved the export of Allied Signal Garrett TFE 731-2A turbofan engine to China despite the strong protest of the US Department of Defence and Arms Control and Disarmament Agency. This agreement licensed the production of this engine in China and it was to 'power the K-8 jet trainer.' But the suspicion that these engines 'could be used in Chinese cruise missiles' soured the project. Till the end of 1995, the licensed production was blocked, but 33 engines were handed over to China (Yuan, 1996). 
The license was issued for the sophisticated Cray supercomputers worth $\$ 8$ million, previously blocked by the Bush (Sr.) administration. Although these computers were to be used for weather forecast by China's State Meteorological Administration but the technology had military application also. It could be used in nuclear and ballistic missile development (Gill, 1998).

Clinton administration preferred to keep China engage through dialogue. Both nations agreed to adopt a step-by-step approach to resolve differences over missile exports, nuclear technology and to cooperate in banning the production of fissile material for nuclear weapons (Gill,1998). China, although did not formally sign but promised to adhere to "Missile Technology Control Regime (MTCR) and agreed to Nuclear Non-Proliferation Treaty (NPT)." In 1996, it also signed Chemical Weapons Convention (CWC) and Comprehensive Test Ban Treaty (CTBT). Next year in 1997, China also joined the Zanger Committee of NPT exporters. In return Clinton administration lifted the sanctions 'under the Arms Export Control Act and the Export Administration Act' (Russia's Road to Corruption, 2000).

High-level exchanges from both sides also facilitated the bilateral energy and defence conversion cooperation accords. As a result the advanced US technology transfers were expected in areas such as the generation of nuclear power and dual-use air-traffic control systems. The US Secretary of Defence William Perry's visit to China for presiding over the meeting of the 'Sino-US Joint Commission on Defence Conversion' helped to enhance bilateral security relations. But the US Congress's suspicion remained there (Tyson, 1997).

In order to curb nuclear proliferation by China, President Clinton signed a nuclear cooperation accord with Chinese President Jiang Zemin, during his state visit to the US (Dumbaugh, 1998). This agreement was a US move to facilitate the US nuclear firms an access to the multibillion-dollar Chinese market (Tyson, 1997) which they lost to their competitors. This agreement was subject to certification by the US president that China was not giving assistance to any country in acquiring nuclear weapons. Earlier, China also promised to export only those nuclear facilities that were open to the international monitoring. China further agreed in a separate agreement to bring its regulations on the export of nuclear and nuclear related technology into line with international standards. New regulations were published in 1997 (Weeks, 1997).

The nuclear agreement provided the legal framework for the sales of nuclear reactors, fuel and components. It also established the basis for cooperation in a variety of applications for the peaceful use of nuclear technology, and the exchange of high technology in the field of health and safety (US-China Nuclear cooperation agreement, 1985). With the enforcement of this agreement, the US companies were authorised to export the nuclear technology. It helped to enhance the bilateral trade and also minimise the trade deficit for the US (Tyson, 1997).

After terrorist attacks in September 2000, United States revised its policy on PRC weapons proliferation. From 2002-2008 the US kept on pressurizing China to use its influence on North Korea to dismantle its nuclear weapons. China organised six-party talks but it did not produce any results. Since 2006, China has adopted a balanced approach and voted for some United Nations Security Council (UNSC) sanctions against missile or nuclear proliferation in North Korea and Iran. However after North Korea's nuclear tests in 2006, 2009 and 2013 US policy-makers reconsidered about how to change China's calculus and the value of its cooperation. China has continued its balanced approach and voted in favour of UNSC resolutions to impose or expand sanctions in 2009, 2010 and 2013. Disagreement developed when China wanted to resume the six party talks, but Obama administration was 
https://ir.iba.edu.pk/businessreview/vol10/iss2/5

DOI: https://doi.org/10.54784/1990-6587.1354

not ready to accept less than complete denuclearization of North Korea. Obama administration also wanted China to reduce crude oil imports from Iran and cooperate in reducing missile proliferation in Iran, North Korea and Syria (Kan, 2014). These moves had positive impact on bilateral relations.

\section{Alternative Sources, the Other Way-out for China}

Both China and the US have divergent views on the issue of technology transfers. Chinese officials did not see the denial of technology transfer consistent with the engagement policy. They had insisted that the technology transfer should be a part of normalisation. The denial on the part of the US had created suspicion about the motives of the engagement policy in China. Under such circumstances, the use of technology transfer as a policy instrument to enhance the US foreign policy goals was a very difficult job for the US administration (Kan, 2014).

Growing economic and technological collaboration between Third World and China as well as close ties with the western countries proved to be a challenge for the US' export control policy. China's engagement in various co-production and co-development projects in defence areas with these countries provided it access to the advanced western military technologies. For example, China, France and Singapore had been engaged in a codevelopment project to design a new helicopter since 1990. The project involved most sophisticated substantial technology transfer in the field of avionics (Defense News, 1990). There are examples when China turned to the alternative suppliers mostly western countries in retaliation to the technology denial from the US, the French and German companies were the beneficiaries in the form of joint ventures while, the US aerospace companies were the losers (Yuan, nd. P. 331-335). In the twenty-first century, when the Chinese scientists are making strides in their relevant fields, the European countries find it inevitable to collaborate with China in scientific research (Brook, nd).

China also used its arm sales relations with the Third World countries to have access to advanced western military technologies. It is believed in the US that China had accessed the American and French weapon technologies in jet fighters, Mirage and F-16, air to air (Sidewinder and Magic) anti-tank missiles (TOW), ship to ship Exocet, and aerial refuelling system from its allies like Pakistan, Iran, Egypt etc. The US export control policy proved to be helpless in this area (Brook, nd).

Effective control over re-export of sensitive products and technology has been another problematic area for the US. The news of reported Israeli technology transfers and reexports to China, shocked the US due to its close ties with Israel. These transfers included advanced tank armours, air-borne early warning radar system, various types of missile and anti-missile system, defence electronics and space program (Israel has stabbed America in the back, 1999). Such issues continued to surface from time to time; in 1992 about Israeli transfer of Patriot missile technology to China (Washington Times, 1992) ${ }^{8}$ and in 1995 about Israeli contract to sale Lavi technology. In 1996, China signed to buy a prototype aircraft which was built by Israel with US technology and funding. It was having Airborne Early Warning and Command and Control (AEW) radar system that could monitor up to a reported

${ }^{8}$ The State Department Inspector-General and US government intelligence agencies had been investigating unauthorized Israeli technology transfers to China, South Africa, Ethiopia, Chile, and other countries. Israeli leaders denied that Israel transferred US technology without US permission, and denied violating US-Israeli agreements on weapons security and transfers.

Published by iRepository, June 2021 
200 targets simultaneously, at a range of 250 miles $(400 \mathrm{~km})$, as well as target surface installations, and gather communications intelligence" (CRS Report, 2000). It was scheduled to hand over first plane to China in October 2001. The US warned Israel that this system in the hands of China would be dangerous especially if China attacked Taiwan. Israeli officials rejected the US interference referring to the sale of Airborne Warning and Control System(AWACS) to Saudi Arabia by the US over the protest of Israel. Israel argued that China could buy AEW from Britain or France and Israel would lose the income from the sale. But the US administration took no action to block $\$ 250$ million military aid to Israel in case of its refusal to cancel the deal with China.

Similarly, the US had close economic ties with Hong-Kong. Hong-Kong's economy was based on trade and high technology transactions. The US had to impose export control on Hong-Kong also to avoid high risk of diversion to mainland China. Since Hong-Kong is now a part of China, the new US guidelines to treat Hong-Kong differently, created confusion and also provoked reaction from the Chinese government (Goldstein, 1993, p, 120). Technology available to Hong Kong is also within the reach of China.

\section{CONCLUSION}

Technology transfer was a need of China for economic development. It was also a source of achieving economic as well as political goals. The US had been using it as a source of achieving policy goals in the early post-Cold War period with considerable success. But the economic cost of these sanctions compelled Washington to review these polices, time and again. Clinton administration liberalised the export control even on dual use technology transfer to China to avoid the economic losses to the US business.

The same considerations convinced the administration to use presidential waiver many times for the export of high technology. Many economic analysts declared it as an opening of a multi-billion dollar trade for the US nuclear technology sector that they lost in the previous years to their competitors France, Germany, Japan etc. Despite the continued sanctions on military technology sales to China military-to-military relations continued between the two countries with a few setbacks.

In the new millennium the US had to face enormous challenges to its security and pre-eminence. China as the emerging power with increasing influence across the continents was also taken as one of the major challenges to the US strategic designs. But at the same time need for strategic engagement and economic cooperation was also realised by the US policy makers. Therefore George W. Bush (Jr.) continued the policy of engagement to resolve the political and economic issues in bilateral relations. Despite the major setback due to bombing in 1999 by NATO forces on Chinese embassy in Belgrade and issue of the US spy plane at the start of new millennium, both nations adopted the conciliatory posture towards each other. The cooperation in the field of trade and direct foreign investment continued along with the denial in high technology transfers.

The terrorist attacks of 11 September 2001 further enhanced the need of bilateral relations and President Bush (Jr.) administration decided to ensure China's cooperation in combating terrorism. China also showed positive response and contributed both by extending political support and economic help in rehabilitation of Afghanistan after the defeat of Taliban.

The US technology control was retrenched following the Cox Committee's report in 1999 over the dual-use satellite technology sale to or launching from China. Consequently the European space industries filled the gap over-riding the US prohibitions. The ultimate losers 
were the US companies which lost the access to a huge potential market. The Chinese leadership concluded that they could draw geostrategic benefits 'from being a partner on the ISS,' symbolic of the "international family of space faring nations." The US 'stiff-arming' behaviour compelled China for 'developing its own space station' (Green, 2009).

With the inauguration of Obama in White House, the new US President preferred dialogue to manage China as a non-challenging power especially in Asia-Pacific in strategic terms and in the world in economic terms. For this purpose, military-to-military talks were resumed. Nonetheless the basic points of disagreements continued to haunt the bilateral relationship. The US demanded more transparency in development of PLA and insisted to address future prospects of 'military maritime incidents.'

The US was not ready to accept the 'PLA's pursuit of area denial and anti-access strategies, including growing threats to US carrier battle groups, satellites and cyberspace (Yuan, 2003). More transparency can help to confidence-building efforts but much more is required to settle down the issues amicably. Its allies in the region including Japan and Australia also shared the US concerns. In order to balance the expanded deployments of 4th generation fighter aircraft by PLA Air Force, Obama administration decided to continue arms sales to Taiwan especially the F-16s, which according to the US are 'critical to maintaining necessary defensive capabilities against China's takeover of Taiwan (Green, 2009).

Countering Obama's policy of extended space cooperation, the US Congress imposed protectionist legislations on China to block such cooperation with China. For instance, 'section 1340 of NASA's budget prohibited NASA and the White House Office of Science and Technology Policy (OSTP) from spending funds to "develop, design, plan, promulgate, implement, or execute a bilateral policy, program, order, or contract of any kind to participate, collaborate, or coordinate bilaterally in any way with China or any Chineseowned company." "The hosting of "official Chinese visitors" at any NASA facility was also restricted. Clear intension of this prohibition was to proscribe the US-China space cooperation. China also responded aggressively as Professor Johnson-Freese noted that those who were supporters of ban thought that "Chinese space officials are anxiously banging on the proverbial US door, waiting and hoping for the opportunity to work with the United States-which just isn't the case." He further wrote that most of Chinese space officials took it as a liability to work with the US on the International Space Station (ISS). Therefore China preferred to broadly move out on their own in space.

The only goodwill gesture from the US side after Cox Commission's Report was the visit of NASA Administrator Mike Griffin's in 2006. But overall policy of President Bush (Jr.) on space cooperation with China had been provocative. Though Obama administration showed positive signs but about cooperation with China, no US-China concrete plan was presented by either side or any in the pipeline. On the other hand, there are countries which are anxious to access China's partnership on space activities. Professor Johnson-Freese wrote that the "US Congress and Obama administration [are] working together to refocus the US space program, including realistic cooperation, would go further to maintain the US space leadership than pointless isolation gestures" (Frees, 2011).

Obama administration also decided'to establish a Strategic and Economic Dialogue' with China as a sign of 'building a cooperative framework for managing bilateral relations.' The "Strategic" part of bilateral negotiations is focused on climate change and energy. The

${ }^{9}$ Joan Johnson-Freese is a Professor of National Security Affairs at the U.S. Naval War
College.

Published by iRepository, June 2021 
US priorities on the "Economic" part would be expected to be focused on issues of currency, global imbalances and trade liberalisation. These discussions helped to create an understanding of each other's interests and perspectives. Obama administration has reactivated the Joint Committee on Commerce and Trade (JCCT) (CRS Report, 2011) ${ }^{10}$ established under the Bush administration as a mode to deal with short term economic issues in bilateral relations (Joint Press Conference of Gates and General Liang, 2011). At the same time Congress continued to build up pressure through protectionist amendments to various China specific bills like punitive tariffs to recent climate change legislation. There is a realisation in the US policy makers that the strategic and economic dialogue is inevitable to manage the sensitive relationship between the two powers. There is also a realisation in the US that China's emerging self sufficiency in military and space technology is a reaction to the US policy of technology denial to China, which virtually proved counterproductive both in strategic and economic terms.

\section{References}

BBC News. (1989). 1989 Massacre in Tiananmen Square. Retrieved From:

http://news.bbc.co.uk/onthis day/hi/dates/stories/june/4/newsid 2496000/2496277.stm, on 20/09/2013.

Brooks Michael . (16 August 2010) The Spark Rises in the East. NewStatesmanhttp://www.newstatesman.com/asia/2010/08/china-research-chinesescience, on 12/10/2014.

Borst, Jay Barry., Sarkani, Shahram., Mazzuchi, Thomas. (2012). Acquisition: US Space Challenges in the Final Frontier. ARJ. 9(1), pp. 75-98.

Bush, H.W. (2011). Retrieved from: www.conservapedia.com/George. Retrieved on $\underline{21 / 03 / 2014 .}$

CNN. (1998). Technology Transfer. Retrieved from: http//www.cnn/us/china.satellite, on 30/12/2014.

Defense News. (Washington) 19 February 1990, 33.

Department of Defense. Joint Press Conference with Secretary Gates and General Liang from Beijing, China. (2011).

Retrievedfromhttp://www.defense.gov/transcripts/transcript.aspx?transcriptid=4750.

Dingding, Xin. (2013).US urged to relax satellite export restrictions. China Daily. Retrieved fromhttp://europe.chinadaily.com.cn/world/2013-01/07/content_16089553.htm. on $22 / 06 / 2014$.

Dumbaugh, Kerry. (1998). US-China Relations. CRS Brief. Retrieved from http://www.fas.org/man/crs/980717CRSRelations.htm, on 25/5/2001.

\footnotetext{
${ }^{10}$ The Joint Commission on Commerce and Trade (JCCT), established in 1983 as a high-level forum for discussion of bilateral trade issues. Like the S\&ED, it is headed on the U.S. side by two cabinet-level officials, in the case of the JCCT, the Secretary of Commerce and the United States Trade Representative. Their Chinese-side counterpart is China's Vice Premier for foreign trade. The JCCT currently includes ten working groups covering trade and investment issues, business development and industrial cooperation, and commercial law, with a side dialogue on export controls.
} 
Dumbaugh, Kerry.(2007).China-U.S. Relations: Current Issues and Implications for U.S. Policy. Retrieved fromopencrs.com/document/RL33877/2007-10-01/download/1005, on 22/12/2013.

Foot, Rosemary. (1995). The Practice of Power: US Relations with China Since 1949. Oxford University Press. Oxford.

Freese, Johnson Joan. (2011). US-China Space Cooperation: Congress' Pointless Lockdown. Retrievedfrom:http://www.chinausfocus.com/peace-security/us-china-space-ooperationcongress $\%$ E2\% 80\% 99-pointless-lockdown/.

Gill, Bates, R. (1993). The Challenges of Chinese Arms Proliferation: US Policy for the 1990s. Strategic studies institute, p 8-9.

Gill, Bates. (June 22, 1998). U.S.-China Technology Transfer: Annotated Timeline 1980January 1998. Retrieved fromhttp://www.nyu.edu/globalbeat/asia/china/0622198gill.html, on 25/5/2001.

Goldstein, M. Steven. (1993). China at the Cross-Roads. Henry Luce Foundation Inc. New York

Green, J. Michael. (2009). US China relations under Obama. The Brooking Institution. Paper was presented in 38th Taiwan-U.S. Conference on Contemporary China.

Hanshan, Charles., Morrison, Wayne. (2000). United States and China. Retrieved from http//usinfo.state.gov/regional/ea/uschina/crsmemo.html, on 21/03/2014.

Holt, Mark and Nikitin, Mary Beth D. (May 6, 2015). The US-China Nuclear Cooperation Agreement. CRS Report. Retrieved from https://www.fas.org/sgp/crs/row/RL33192.pdf http//www.ksgnotes1.Harvard.edu/BCSIA/Library.nsf/pubs/US-Chi-Nuclear, on 22/06/2001.

Investigation of Israeli's transfer of technology. (1992). The Washington Times.

Israel has stabbed America in the back. (1999). Retrieved fromhttp://zog,to/3/zog/111199Ic.htm, on 12/10/2010.

Israel's Sale of Airborne Early Warning Aircraft to China. (2000). CRS Report RS20583. Jisi, Wang (Ed.). (2012). China at the Crossroads: Sustainability, Economy, Security and Critical Issues for the 21st Century. Polity Press, Cambridge.

Jr. Fisher, D. Richard. (1998). Commercial Space Cooperation should not Harm National Security. Retrieved From: http://www.heritage.org/research/reports/1998/06/bg1198escommercial-space- cooperationnbspnbsp; on 12/09/2011.

Kan, Shirley, A. (2014). China and Proliferation of weapons of mass destruction. Congressional Research $\quad$ service. $\quad$ Retrieved https://www.fas.org/sgp/crs/nuke/RL31555.pdf,on22/6/2014.

Leuenberger, Theodor. (2012). From Technology Transfer to Technology Management in China. Springer Science \& Business Media. New York.

Malin, Martin. (2010)U.S.-China Experts Meet to Strengthen Nuclear Cooperation. Belfer Center Newsletter. Harvard Cannedy School.

Meeting of the Steering Committee of US-China Bilateral Action Plan. (2014). Retrieved from: http://energy.gov/ne/international-nuclear-energy-policy-and-cooperation/bilateralcooperation, on $12 / 06 / 14$.

Miller, Das. (1998). Technology Transfer to China. Retrieved From: http//:www.usinfo/gov, on 06/4/2014.

Nau, R. Henry., Behrman, H. Jack., Wallender, W. Harvey. (1976). Technology transfer and US foreign. Praeger Publishers. New York.

New York Times. (1 May 1991)., p. A1. 
Nolt, H. James. (2001). US-China Security Relations. Retrieved From: http://www.foteignpolicy-Infocus.org/briefs/vol13/v3n19chi body.html, on 22/06/2014.

Nurkin, Tate., Burton, Paul., Skomba, Tom. \& Hardy, James. (19 May 2014). The Global

Implications of China's military modernization. IHS Quarterly. Retrieved

fromhttp://www.ihs.com/tl/quarterly/features/chinas-military-modernization.aspx, on $22 / 06 / 2014$.

Qingshan, Tan. (1992). The Making of U.S. China Policy: From Normalization to the PostCold War Era. Lynne Rienner Publishers. Boulder.

Reddy, C. Allan. (1996). A Macro Perspective on Technology Transfer. Greenwood Publishing Group. Portsmouth.

Reiss, Mitchell \& Litwak, S. Robert. (1994). Nuclear Proliferations after the Cold War Woodrow Wilson Centre Press.Washington D.C.

Rennack, E. Dianne, (2006). China: Economic Sanctions. CRS Report. https://www.fas.org/sgp/crs/row/RL31910.pdf. 28.

Report of the Commission to Assess the Ballistic Missile Threat to the United States. (1998). Retrieved from: http://www.fas.org/irp/threat/bm-threat.htm.

Report of the selected committee of the House of Representatives. U.S. National Security and Military/Commercial Concerns with the People's Republic of China. Retrieved From: http://www.house.gov/coxreport/. Retrieved on 12/09/2013.

Russia's Road to Corruption. (2000). Retrieved from http://perminant.access.gpo.gov/Ips6132/russisroadtocorruption.pdf, on22/3/10.

Schnepp, Otto. (2008). U.S.-China Technology Transfer: Problems and Solutions. Woodrow Wilson Center of the Smithsonian Institution. Washington.

Stumbaum,U. Britt, Mat. (2009). Risky Business, The EU-China dual Use Technology Transfer. European Union Institute of Security Studies. Occasional Paper. Retrieved from: www.iss.europa.eu.pdf.

Tyson, Scott, Ann. (1997). Nuclear Deal Tightens U.S.-China Ties. Retrieved from http://www.csmonitor.com/durable/1997/ 10/30/intl.7.html, on 25/5/2001.

U.S.-China Relations: Policy Issues. (2011). CRS Report.

US-China cooperation agreement (transcript). (1985). Retrieved from http://findarticles.com/p/articles/mi_m1079/is_v85/ai_3956329/, on 25/6.2014.

Washington Post, 19 December 1989, A1.

Weeks, Jennifer. (1997). US-China Nuclear Cooperation Agreement. Testimony before Congress Committee. Retrieved

fromhttp://belfercenter.hks.harvard.edu/publication/3250/uschina_nuclear_cooperation_agree ment.html, on $25 / 5 / 2001$.

Work Begins on Nuclear Security Center in China. (2013). Retrieved from

http://www.nti.org/gsn/article/us-china-nuclear-security-cooperation-concerns-some/, on $12 / 06 / 14$.

Yuan, Dond, Jing. (1996). United States Technology Transfer Policy towards China: postCold War Objectives and Strategies. International Journal, vol. 1, no. 2, pp. 314-338.

Yuan, Dong, Jing. (1995). The Politics of the Strategic Triangle: the United States, COCOM and Export Control on China. Journal of Northeast Asian Studies. 4, pp. 47-79.

Yuan, Dong, Jing. (2003). Sino-US military relations since Tiananmen: Restoration, Progress, and Pitfalls. Parameters. 